\title{
Morphological and morphometric features of nematode-cysts in Gymnotus inaequilabiatus liver in the Brazilian Pantanal
}

\author{
Características morfológicas e morfométricas de cistos de nematódeos em fígado de Gymnotus inaequilabiatus \\ no Pantanal brasileiro
}

\author{
Gizela Melina Galindo ${ }^{1}$; Robson Andrade Rodrigues ${ }^{1}$; Sandriely Fernanda Marcondes ${ }^{1}$; Priscilla Soares ${ }^{2}$; \\ Luiz Eduardo Roland Tavares; Carlos Eurico Fernandes ${ }^{1 *}$
}

\begin{abstract}
${ }^{1}$ Laboratório de Patologia Experimental, Centro de Ciências Biológicas e da Saúde - CCBS, Universidade Federal de Mato Grosso do Sul - UFMS, Campo Grande, MS, Brasil

${ }^{2}$ Laboratório de Parasitologia Animal, Centro de Ciências Biológicas e da Saúde - CCBS, Universidade Federal de Mato Grosso do Sul - UFMS, Campo Grande, MS, Brasil
\end{abstract}

Received January 23, 2017

Accepted June 2, 2017

\begin{abstract}
The aim of this study was to determine the morphometric measures and morphological aspects of nematode-cysts in Gymnotus inaequilabiatus, and the presence of melanomacrophage centers (MMCs) associated with the periphery of cysts and in the liver parenchyma. Adult specimens, 34 female $(123.1 \pm 43.9 \mathrm{~g})$ and 45 male $(135.5 \pm 43.4 \mathrm{~g})$, from Paraguay River, Corumbá, Brazil, were used. The number of nematode-cysts was determined in 79 livers and 25 of them randomly selected for histopathological analysis and morphometric measures of nematode-cysts (mean diameter, thickness of collagen layer, and cyst-wall layer). The percentage of cysts with MMCs on the periphery and density in the liver parenchyma was estimated. The average number of macroscopic cysts was of $48.7 \pm 2.78$. Granulomatous reaction was observed surrounding the cysts. Diameter, collagen layer and cyst-wall measurements were $293.0 \pm 75.18(\mu \mathrm{m}), 17.72 \pm 6.01(\mu \mathrm{m})$ and $12.21 \pm 9.51(\mu \mathrm{m})$, respectively. The number of nematode-cysts was correlated with hepatosomatic index, $(r=0.26, \mathrm{P}<0.05)$. Collagen layer was correlated with cyst diameter $(r=0.62, \mathrm{P}<0.01)$. Pericystic and parenchymatous MMCs were moderately $(\mathrm{r}=0.48)$ and highly $(\mathrm{r}=0.90)$ correlated with nematode-cysts number. Morphological characteristics of hepatic tissue and cysts-nematodes measures suggest that $G$. inaequilabiatus acts as a paratenic host to nematodes in the larval stage.
\end{abstract}

Keywords: Brevimulticaecum sp., Gymnotiformes, nematoda, melanomacrophages.

\section{Resumo}

O objetivo deste estudo foi determinar as características morfológicas e morfométricas de cistos de nematodas em fígado de Gymnotus inaequilabiatus, e a presença de centros de melanomacrófagos (CMMs) pericísticos e no parênquima hepático. Espécimes adultos, 34 fêmeas $(123,1 \pm 43,9 \mathrm{~g})$ e 45 machos $(135,5 \pm 43,4 \mathrm{~g})$, provenientes do Rio Paraguai, Corumbá, Brasil foram utilizados. Os cistos foram quantificados em 79 fígados. Em 25 fígados foi realizada a análise histopatológica e morfometria dos cistos (diâmetro, espessura da camada de colágeno e da parede). Estimou-se a porcentagem de cistos com CMMs periférico e a densidade de CMMs no parênquima. A média de cistos macroscópicos foi de 48,7 $\pm 2,78$. Observou-se reação granulomatosa pericística. O diâmetro, a espessura da camada de colágeno e da parede do cisto foi de $293,0 \pm 75,18(\mu \mathrm{m}), 17,72 \pm 6,01(\mu \mathrm{m})$ e $12,21 \pm 9,51(\mu \mathrm{m})$, respectivamente. O número de cistos foi associado ao índice hepatossomático, $(\mathrm{r}=0,26, \mathrm{P}<0,05)$. A camada de colágeno correlacionou-se com o diâmetro do cisto $(\mathrm{r}=0,62, \mathrm{P}<0,01)$. CMMs pericísticos e do parênquima apresentaram correlação moderada $(\mathrm{r}=0,48)$ e alta $(\mathrm{r}=0,90)$ com o número de cistos, respectivamente. As características morfológicas do tecido hepático e a morfometria dos cistos de nematodas sugerem que G. inaequilabiatus atua como hospedeiro paratênico para larvas de nematodas.

Palavras-chave: Brevimulticaecum sp., Gymnotiformes, nematoda, melanomacrófagos.

\footnotetext{
*Corresponding author: Carlos Eurico Fernandes. Laboratório de Patologia Experimental, Centro de Ciências Biológicas e da Saúde - CCBS, Universidade Federal de Mato Grosso do Sul - UFMS, Av. Costa e Silva, s/n, Bairro Universitário, CEP 79070-900, Campo Grande, MS, Brasil. e-mail: carlos.fernandes@ufms.br
} 


\section{Introduction}

The Gymnotiformes constitute a small endemic group of Neotropical ichthyofauna (REIS et al., 2003). The family Gymnotidae has the widest geographical distribution within the order, ranging from central Argentina to the southeast of Mexico (ALBERT, 2001). The Gymnotus inaequilabiatus (Actinopterygii: Gymnotiformes) is popularly referred to as "tuvira" or "sarapó," and, in general, it is active at night in aquatic macrophyte under lentic environments. These conditions provide a suitable habitat for the fish to feed on insects, their preferred food (GRASS \& HÖFLING, 1992; PEREIRA \& RESENDE, 2006). In the Pantanal region, these fish experience the transition from dry to flood seasonal conditions and may have developed adaptive physiological strategies to survive. During these periods, many fish species are subjected to adverse situations such as large temperature fluctuations, food scarcity and a broad spectrum of pathological agents (BRITSKI et al., 2007; BARTON et al., 2002, RIOS et al., 2005). In this context, parasitic infections are extremely common, particularly in wild populations from different aquatic environments. The synergism between lethal and sublethal parasitic infections and the population structure is a complex issue and many aspects are yet unknown (FEIST \& LONGSHAW, 2008).

The liver is a large organ of the body and plays a central role in metabolic functions. It is usually located in the anterior portion of coelomic cavity and is vascularized by hepatic artery and portal veins. The vascular system is distributed in small capillaries which give rise to the sinusoidal network. The surface of the liver is encapsulated by a serous membrane and the connective tissue remains invaginated into parenchyma (TAKASHIMA \& HIBIYA, 1995). Similar to high vertebrates, hepatocytes are concentrically arranged around the sinusoids forming organized cordonal structures. The architecture of hepatocyte-sinusoidal structures in teleosts can be used for phylogenetic classification and ontogeny of liver among species (AKIYOSHI \& INOUE, 2004).

Several hepatic alterations are reported in studies of diseases that affect the structure of the liver in fishes. In parasite infections, cysts constitute a usual structure of nematodes, however, their pathological effects are in accordance with infection intensity, migration capability and tissue damage. This can vary between nematodes species (MOLNÁR et al., 2006; SANTOS et al., 2013). Macroscopic lesions of infected fish include discoloration of parenchyma, nodules of variable sizes, petechial hemorrhage, whether or not accompanied by jaundice (BRUNO et al., 2013). Inflammatory reaction and vascular lesions are common during larvae migration (VALTONEN et al., 1994). In anisakis larvae, the invasion is associated with parenchymatous necrosis, hemorrhage and sometimes thrombus formations (SMITH, 1984). However, most of this process is chronic, accompanied by macrophages, giant cells, fibroblasts and eosinophilic granule cells, composing a granulomatous reaction (REITE, 2005; FERGUSON, 2006). In this context, macrophages aggregates known as melanomacrophages centers play a crucial role. These structures are distinctive groupings of pigment containing cells from the reticulo-endothelial supporting matrix in the hematopoietic tissues such as spleen and kidney (AGIUS \& ROBERTS, 2003). The function of melanomacrophages is involved with the phagocytosis of heterogeneous materials, for example cell debris, melanin pigments, hemosiderin granules and lipofuscin residues. Additionally, they can be associated with inflammatory reaction in resistant pathogens such as bacterial and parasitic spores (WOLKE, 1992; AGIUS \& ROBERTS, 2003).

The aim of this study was to determine different measures and morphological aspects of nematode-cysts in $G$. inaequilabiatus from the Brazilian Pantanal. Additionally, we investigated the melanomacrophage centers (MMCs) associated with the periphery of cysts and in the liver parenchyma.

\section{Materials and Methods}

Adult $G$. inaequilabiatus specimens ( $\mathrm{n}=79), 34$ female $(123.1 \pm 43.9 \mathrm{~g})$ and 45 male $(135.5 \pm 43.4 \mathrm{~g})$, from Paraguay River, Corumbá, Brazil, were acquired from a fishing community. The specimens were transported in oxygenated polyethylene bags to the Laboratory of Pathology, CCBS, UFMS, Campo Grande. In the laboratory, the fishes were maintained in aquariums supplied with artificial aeration at constant temperature $\left(25.0^{\circ} \mathrm{C}\right)$ until euthanasia (2-Fenoxietanol, $2 \mathrm{~mL} / \mathrm{L}$ ), approximately $3-5$ days after transport. After that, the fishes were weighed (total weight in grams) and measured (total length in centimeters). These variables were used to estimate the relative condition factor $(\mathrm{Kn})$ according the formula $\mathrm{Kn}=W / a L^{B}$, where: $W$ is the weight of the individual, $L$ is the total length of the individual, and $a$ and $b$ are the constants relating weight to length (CREN, 1951). The liver was removed from the coelomic cavity and weighed to estimate the hepatosomatic index $(\mathrm{HSI}=$ liver weight $(\mathrm{g}) /$ total weight $(\mathrm{g}) \times 100)$.

The encysted larvae were identified in $11.2 \%$ of livers randomly selected. For this, the tissues were digested in hydrochloric acid and pepsin according to Xi \& Jin (1998). After digestion, the material was centrifuged at $1,500 \mathrm{rpm}$ for 2 minutes. The sediment was suspended in a $0.7 \%$ sodium chloride solution. Larvae were fixed in 5\% formalin and clarified in lactophenol, then examined using differential interference contrast microscopy and identified according to Moravec (1998).

The livers were fixed in a $10 \%$ formalin buffer solution for $24 \mathrm{~h}$. Cyst number was estimated on the livers surface and from the inside of them. A longitudinal fragment on the major lobule was histologically processed. The samples were dehydrated in ethanol, embedded in paraffin and $5 \mu \mathrm{m}$ sections were then stained with hematoxylin and eosin (H\&E) and Masson's Trichrome (MT). An initial examination was conducted to determine possible histopathological changes in the architecture and tissue organization. If present, alterations were classified as regressive, inflammatory, circulatory or progressive in origin.

Morphometric analysis of cysts $(\mathrm{n}=410)$ was performed on 25 histological sections randomly selected using MT. The diameter $(\mu \mathrm{m})$, thickness of cyst wall layer $(\mu \mathrm{m})$ and collagen layer $(\mu \mathrm{m})$ were measured in at least 10 nematode-cysts in 5 images/section at $100 \times$ and $400 \times$ magnification. Images were captured with a Nikon camera (D3100) adapted for bright light microscopy (P95-T2 1,6x DSLR/Primo Star, Zeiss). The measures were processed using Motic Image Plus 2.0 software (Motic Asia, Hong Kong). The mean diameter, thickness of collagen layer, and cyst-wall layer 
were determined based on four perpendicular measurements of each cystic structure. The percentage of cysts with MMCs on the periphery was calculated using the same samples of MT $(n=25)$ which were stained with H\&E. Next, the density of MMCs was estimated in the liver parenchyma. Images ( $n=10 /$ section) in $400 \times$ magnification were considered. A grid (266 intersections points) was introduced and the MMCs present at each intersection were counted and the relative frequency (\%) was estimated (MMCs density = count $/ 266 \times 100)$. The Image J $1.45 \mathrm{M}$ software was used for this analysis (ABRÀMOFF et al., 2004).

Data were analyzed using descriptive statistics, considering the general mean, standard deviation and range to $25^{\text {th }}$ and $75^{\text {th }}$ percentiles. No differences were observed between females and males ( $P>0.05$, T-test) and sex was not considered in the analysis. Pearson's correlation (bivariate model) was used to verify the association level within both the macroscopic and microscopic data sets.

\section{Results}

The liver of Gymnotus inaequilabiatus harbors two distinct lobes localized in the ventral portion of the coelomic cavity, both situated above the stomach and intestine. The first and more prominent lobe is located on the left side, while the second, which is smaller and elongated, is localized on the right side. This lobe is divided in two portions positioned in the caudal direction. The parasitic structures extend throughout the hepatic surface and into the parenchyma in both lobes. Some livers were characterized by substantial lobar deformity due the superficial projection of the cyst structures. Larvae were usually located on the inner face of cysts, either partially or completely filling the cystic space (Figure 1a, b). Macroscopy and microscopy data are described in Table 1. Of the total specimens observed $87.3 \%$ (69/79) presented macroscopic cystic structures, and the average number of these was $48.7 \pm 2.78$. However, microscopic evaluation revealed a $100.0 \%$ rate of infection of the livers by nematodes. The percentage of pericystic MMCs was the most variable. A total of 1,370 larvae (L3 stage) were identified: $85.8 \%$ were Brevimulticaecum sp. (Nematoda: Anisakidae), 5.5\% of the order Ascaridoidea (Nematoda), 0.1\% Porrocaecum sp. (Nematoda: Ascarididae) and 8.6\% were unidentified.

General organization and tissue architecture of $G$. inaequilabiatus were similar to other teleosts. Hepatocytes are uniformly distributed with a homogeneous eosinophilic cytoplasm arranged in groups parallel to the sinusoidal space. The nuclei were localized in the center of the hepatocytes and had a prominent nucleolus. We did not find any evidence of portal tracts or lobular organization in the parenchyma. Arteries, vessels, and capillaries were randomly distributed throughout the parenchyma. Bile ducts were composed of columnar epithelia surrounded by a connective tissue framework and distributed randomly among the parenchyma.

The nematode-cysts were aligned in a collagenous external capsule with variable levels of thickness (Figure 2a). In some sections, it was possible to identify protein deposits associated with the basophilic amorphous material, suggesting necrosis (Figure 2c, d). Although the structures that surround the cysts configure a granulomatous reaction, degenerative cells and extensive inflammatory reactions, including multinucleated


Figure 1. Macroscopic aspects of liver and nematode-cysts in Gymnotus inaequilabiatus. (a) and (b) Livers pre-fixation; cysts are diffusely distributed in the parenchyma surface (bar scale $=1 \mathrm{~cm}$ ); (c) and (d) Livers post-fixation, cystic space are partially or totally filled by larvae of nematodes. Detail of nematodes larvae inside of cysts. Two larvae in the same cyst are usually observed (d). (c), bar scale $=0.5 \mathrm{~cm}$; (d), bar scale $=1 \mathrm{~mm}$. 
giant cells were not identified. Discrete sinusoidal spacing with erythrocytes was observed in some sections without relation with the cyst structures. Besides MMCs periphery, some eosinophilic granule cells were found surrounding the cysts, but these were not quantified (Figure 2b).

Table 1. Descriptive data of macroscopic and microscopic variables observed in Gymnotus inaequilabiatus from the Brazilian Pantanal.

\begin{tabular}{lrrrc}
\hline \multicolumn{1}{c}{ Macroscopic* } & Mean & \multicolumn{1}{c}{ S.D. } & $\mathbf{2 5}^{\text {th }}$ & $\mathbf{7 5}^{\text {th }}$ \\
\hline Body weight $(\mathrm{g})$ & 137.00 & 30.64 & 114.5 & 157.1 \\
Total length $(\mathrm{cm})$ & 34.31 & 2.78 & 32.5 & 35.9 \\
Relative condition factor Kn & 0.34 & 0.07 & 0.29 & 0.39 \\
Liver weight $(\mathrm{g})$ & 0.77 & 0.23 & 0.63 & 0.89 \\
Hepatosomatic index $(\%)$ & 0.56 & 0.12 & 0.48 & 0.63 \\
Nematode-cysts $(\mathrm{n})$ & 48.71 & 57.05 & 9.80 & 64.0 \\
$\quad$ & & & & \\
$\quad$ Microscopic** & 293.0 & 75.18 & 215.54 & 395.40 \\
Cyst-diameter $(\mu \mathrm{m})$ & 17.72 & 6.01 & 0.00 & 20.23 \\
Cyst-collagen layer $(\mu \mathrm{m})$ & 12.21 & 9.51 & 12.86 & 22.69 \\
Cyst-wall $(\mu \mathrm{m})$ & 2.74 & 1.81 & 0.82 & 3.80 \\
MMCs density $(\%)$ & 5.21 & 7.59 & 1.00 & 6.00 \\
Pericystic MMCs $(\%)$ & &
\end{tabular}

*Estimated in 79 specimens; ${ }^{* *}$ Estimated in 410 cyst-nematodes observed in 25 livers randomly selected; MMCs, melanomacrophages centers.
Pearson's correlation coefficients are described in Table 2 and 3 to macroscopic and microscopic data, respectively. The number of nematode-cysts was associated only with hepatosomatic index $(\mathrm{r}=0.26 ; \mathrm{P}<0.05)$. The microscopic data revealed a significant and moderate association between collagen layer and cyst diameter $(\mathrm{r}=0.62, \mathrm{P}<0.01)$. Nevertheless, parenchyma and pericystic MMCs were moderate and highly associated with nematode-cysts number $(\mathrm{r}=0.48$, and $\mathrm{r}=0.90$, respectively).

\section{Discussion}

Nematodes constitute an important group of parasites in freshwater fish. They are typically found in fish digestive tracts; however, they can eventually migrate to other organs such as the muscle, liver, and serous membrane. Although nematode pathogenesis and distribution in host organs have been thoroughly studied, both biotic and abiotic factors may affect them severely (PAVANELLI et al., 2013). In lentic habitat, Gymnotus spp. are adapted to low oxygen rate alongside a wide range of plant material and sludge in the river sediment deposition. Furthermore, this species has a gregarious behavior with low migration rate and without expressive variations in their diet (ROTTA, 2004). These characteristics suggest that nematodes diversity and infection rates can depend on habitat and, therefore, extensively variable.


Figure 2. Histological sections of cyst-nematodes in Gymnotus inaequilabiatus. (a) Cysts structures widespread in liver parenchyma. The cysts present ample variety of sizes, formats and thickness of pericystic layer with remarkable inner larvae deposition. There is no evidence of pronounced inflammatory process into parenchyma or next to cysts; (H\&E, scale bar $=200 \mu \mathrm{m}$ ); (b) Eosinophilic granule cells deposition surrounding a cyst-wall. There is a formation of connective tissue framework and collagen fibers bellow the cell layer; (H\&E, scale bar $=20 \mu \mathrm{m}$ ); (c) Cysts exhibiting extensive internal amorphous material. Melonomacrophages centers are deposited around of the collagen layer; $(\mathrm{H} \& \mathrm{E}$, scale bar $=50 \mu \mathrm{m})$; (d) Two cysts covered by a thick collagen layer. Cystic-wall (dark blue lamina) delimits the larvae structures. Extensive necrotic debris (red) are usually found inside; (TM, scale bar $=50 \mu \mathrm{m})$. 
Table 2. Pearson's Correlation coefficients between biometric body variables (total length, total weight and relative condition factor Kn), liver variables (liver weight and hepatosomatic index) and liver nematode-cysts count in Gymnotus inaequilabiatus ( $\mathrm{n}=79$ ) from the Brazilian Pantanal.

\begin{tabular}{|c|c|c|c|c|c|}
\hline & Total weight (g ) & $\begin{array}{l}\text { Relative condition } \\
\text { factor } \mathbf{K n}\end{array}$ & Liver weight (g) & HSI & $\begin{array}{l}\text { Nematode-cysts } \\
\text { count }\end{array}$ \\
\hline Total length $(\mathrm{cm})$ & $0.65^{* *}$ & 0.71 & $0.44^{* *}$ & -0.07 & 0.13 \\
\hline Total weight $(\mathrm{g})$ & -- & -0.10 & $0.66^{* *}$ & -0.11 & -0.12 \\
\hline Relative condition factor $\mathrm{Kn}$ & & -- & -0.82 & -0.02 & 0.16 \\
\hline Liver weight $(\mathrm{g})$ & & & -- & $0.65^{* *}$ & 0.08 \\
\hline HSI & & & & -- & $0.26^{*}$ \\
\hline
\end{tabular}

${ }^{*} \mathrm{P}<0.05 ;{ }^{* *} \mathrm{P}<0.01 ; \mathrm{HSI}=$ Hepatosomatic index.

Table 3. Pearson's Correlation coefficients between morphometric measures of nematode-cysts $(n=140)$, pericystic melanomacrophages centers (MMCs) and pericystic mast cells (MCs) in Gymnotus inaequilabiatus from the Brazilian Pantanal.

\begin{tabular}{lccccc}
\hline & Diameter $(\mu \mathrm{m})$ & Collagen layer $(\mu \mathrm{m})$ & Cyst-wall $(\boldsymbol{\mu m})$ & $\begin{array}{c}\text { Parenchyma MMCs } \\
(\%)\end{array}$ & Pericystic MMCs $(\%)$ \\
\hline Nematode-cysts count & 0.20 & 0.22 & 0.33 & $0.48^{* *}$ & $0.90^{* *}$ \\
Diameter $(\mu \mathrm{m})$ & -- & $0.62^{*}$ & -0.10 & 0.19 & 0.11 \\
Collagen layer $(\mu \mathrm{m})$ & -- & -0.10 & 0.41 & 0.18 \\
Cyst-wall $(\mu \mathrm{m})$ & & -- & -0.33 & 0.36 \\
Parenchyma MMCs $(\%)$ & & & -- & 0.30 \\
\hline
\end{tabular}

${ }^{*} \mathrm{P}<0.01 ;{ }^{* *} \mathrm{P}<0.05$.

In Gymnotus spp., the prevalence of nematodes ranges from $1.8 \%$ to $66.7 \%$, and these parasites are mainly located in the mesenteries, intestinal caecum, intestine, gonads, liver, and skeletal muscle (ISAAC et al., 2004; VIEIRA et al., 2010). In the present study, $11.2 \%$ of the livers assessed showed a higher prevalence of Brevimulticaecum sp., in accordance with what was found by Vieira et al. (2010), but less with Ventura et al. (2016). However, liver infection by nematodes in Gymnotus spp. is not clearly understood and little is known about the pathogenesis of immune response to these parasites. Furthermore, the biological cycle of Brevimulticaecum sp. has not been completely elucidated, although general pathological aspects have been identified in other species (CARDOSO et al., 2012) leading us to suppose it is similar with regards to this nematode species. Nematodes cause infectious without apparent extensive pathological symptoms. After encapsulation, larvae are isolated and are often destroyed (FEIST \& LONGSHAW, 2008). In the digestive tract, where larval migration rates are higher, the inflammatory response is greater in the presence of multinucleated giant cells (BRUNO et al., 2013), which seems not to happen to the liver of this species.

Larval forms can be found on the peritoneum or coelomic viscera coated by fibrous connective tissue, macrophages, neutrophils, and eosinophilic granule cells (POOLE \& DICK, 1984; DEZFULI et al., 2000; FERGUSON, 2006). Due the proximity of these viscera, larvae might migrate to the liver, adhere to the surface, and penetrate into parenchyma. Although this has not been quantified, the superficial edge of the liver tends to be more affected by parasites than the inner portions. The largest cysts harbor a thicker collagen-layer, which might indicate a chronic reaction in older larvae with higher deposition time. These findings suggest that the vascular via was not used by these nematodes in G. inaequilabiatus, since vascular alterations such as perivascular inflammatory reaction, coagulative necrosis, and edematous areas, as well as obstructive thrombosis, were not observed, in contrast to other studies (SZÉKELY et al., 1996; VENTURA et al., 2016). Based on the amount of cyst structures found after the macroscopic and microscopic assessment, we inferred that this organ is a critical site of nematode infection. The deposition of encysted forms did not affect the liver function, since degenerated hepatocytes or extensive granulomatous reactions were not observed, in contrast to what has been reported on other species of fish affected by parasites (SZÉKELY et al., 1996; FERGUSON, 2006; FEIST \& LONGSHAW, 2008). Furthermore, the condition factor Kn was not associated with the liver cyst-nematode number, suggesting that $G$. inaequilabiatus might not be sensitive to liver nematode infracommunities. The positive correlation between nematode-cyst number and hepatosomatic index indicate that parasitized livers tend to become heavier.

A variety of cystic conditions have been reported in several fish species. Parasitic cysts are probably the most common and are characterized by a range of morphological features. Consequently, different histopathological aspects are observed and reported in the literature based on the degree of infection, tissue affected, host immune system, and magnitude of inflammatory response (POOLE \& DICK, 1984; ALVAREZ-PELLITERO, 2008; ROBERTS, 2012). Microscopic examinations have revealed insignificant tissue changes despite evidence of considerable infection in most histological sections, indicating the complex interactions between the pathogen and host as well as the difficulty in establishing pathological patterns related to lethality in fish under natural conditions according to Poulin (1992) and Guidelli et al. (2011). In addition, samples of larvae in the L3 stage remained in the tissue with irrelevant deleterious effect, reducing the pathogenicity and probably the mortality in this fish species.

Two distinct layers identified by MT technique were observed in all cysts. In the inner cyst-wall, the layer was dense and darkly 
colored, covered by an external fibrous layer (Figure $2 \mathrm{~d}$ ). These aspects demonstrate the effectiveness of the encapsulation and isolation process by nematode larvae. In this context, pericystic MMCs play a central role in the tissue response. Deposits of MMCs distributed diffusely in the liver parenchyma and surrounded by foreign corpus are important marks of tissue alterations and contamination by microorganisms and are associated with immune response of the organ (AGIUS \& ROBERTS, 2003). In this context, the positive association between nematode-cysts numbers in liver with pericystic MMCs and in the parenchyma indicates that the increase of cystic forms induced a prompt cell response mediated by MMCs in all hepatic tissue of $G$. inaequilabiatus.

We conclude that the livers of $G$. inaequilabiatus are strongly parasitized by nematodes, and the Brevimulticaecum spp. larvae are an important group in this process. The lack of liver injury associated with massive parasite infection, changes in cyst measurements and MMCs response, suggest that $G$. inaequilabiatus acts as a paratenic host for nematodes, particularity species in the larval stage. Future studies could address the ultrastructural analysis of cysts as well as the specific immune cell response in order to elucidate the pathobiological phenomena of liver infection by nematodes in this species.

\section{References}

Abràmoff MD, Magalhães PJ, Ram SJ. Image processing with ImageJ. Biophoton Int 2004; 11(7): 36-42.

Agius C, Roberts RJ. Melano-macrophage centres and their role in fish pathology. J Fish Dis 2003; 26(9): 499-509. PMid:14575368. http:// dx.doi.org/10.1046/j.1365-2761.2003.00485.x.

Akiyoshi H, Inoue A. Comparative histological study of teleost livers in relation to phylogeny. Zoolog Sci 2004; 21(8): 841-850. PMid:15333997. http://dx.doi.org/10.2108/zsj.21.841.

Albert JS. Species diversity and phylogenetic systematics of American knifefishes (Gymnotiformes, Teleostei). Ann Arbor: Miscellaneous Publications; 2001. p. 1-127. no. 190.

Alvarez-Pellitero P. Fish immunity and parasite infections: from innate immunity to immunoprophylatic prospects. Vet Immunol Immunopathol 2008; 126(3-4): 171-198. PMid:18783835. http://dx.doi.org/10.1016/j. vetimm.2008.07.013.

Barton BA, Morgan JD, Vinayan MM. Physiological and conditionrelated indicators of environmental stress in fish. In: Adams M. Biological indicator of aquatic ecosystem stress. Bethesda: American Fisheries Society; 2002. p. 289-320.

Britski HA, Silimon KZS, Lopes BL. Peixes do Pantanal: manual de identificação. Brasília: Embrapa; 2007.

Bruno D, Noguera PA, Poppe TT. A colour atlas of salmonid diseases. London: Springer; 2013.

Cardoso AMC, Souza AJS, Menezes RC, Pereira WLA, Tortelly R. Gastric lesions in free-ranging black caimans (Melanosuchus niger) associated with Brevimulticaecum species. Vet Pathol 2012; 50(4): 582 584. PMid:22961885. http://dx.doi.org/10.1177/0300985812459337.

Cren EDL. The length-weight relationship and seasonal cycle in gonad weight and condition in the perch (Perca fluviatilis). J Anim Ecol 1951; 20(2): 201-219. http://dx.doi.org/10.2307/1540.
Dezfuli BS, Simoni E, Rossi R, Manera M. Rodlet cells and other inflammatory cells of Phoxinus phoxinus infected with Raphidascaris acus (Nematoda). Dis Aquat Organ 2000; 43(1): 61-69. PMid:11129382. http://dx.doi.org/10.3354/dao043061.

Feist SW, Longshaw M. Histopathology of fish parasite infections importance for populations. J Fish Biol 2008; 73(9): 2143-2160. http:// dx.doi.org/10.1111/j.1095-8649.2008.02060.x.

Ferguson HWF. Systemic Pathology of Fish: A text and atlas of normal tissues in teleosts and their responses in disease. London: Scotian Press; 2006.

Grass LEA, Hofling JC. Regime alimentar de Gymnotus "aft" carapo em uma lagoa do Ribeirão Pinhal. Bioikos 1992; 6(1-2): 18-35.

Guidelli G, Tavechio WLG, Takemoto RM, Pavanelli GC. Relative condition factor and parasitism in anostomid fishes from the floodplain of the Upper Paraná River, Brazil. Vet Parasitol 2011; 177(1-2): 145-151. PMid:21176864. http://dx.doi.org/10.1016/j.vetpar.2010.11.035.

Isaac A, Guidelli GM, França JG, Pavanelli GG. Composição e estrutura das infracomunidades endoparasitárias de Gymnotus spp. (Pisces: Gymnotidae) do rio Baía, Mato Grosso do Sul, Brasil. Acta Sci Biol Sci 2004; 26(4): 453-462. http://dx.doi.org/10.4025/actascibiolsci.v26i4.1527.

Molnár K, Buchmann K, Székely C. Phylum Nematoda. In: Woo, PTK. Fish Diseases and Disorders. 2nd ed. Cambridge: CAB International; 2006. p. 417-443. vol. 1. Protozoan and Metazoan Infections.

Moravec F. Nematodes of freshwater fishes of the Neotropical Region. Czech Republic: Academia Praha; 1998.

Pavanelli GC, Takemoto RM, Eiras JC. Parasitologia de peixes de água doce do Brasil. Maringá: Eduem; 2013.

Pereira RAC, Resende EK. Alimentação de Gymnotus cf carapo (Pisces: Gymnotidae) e suas relaçôes com a fauna associada às macrófitas aquáticas no Pantanal, Brasil. Corumbá: Embrapa Pantanal; 2006.

Poole BC, Dick TA. Liver pathology of yellow perch, Perca flavescens (Mitchill), infected with larvae of the nematode Raphidascaris acus (Bloch, 1779). JWildl Dis 1984; 20(4): 303-307. PMid:6530717. http://dx.doi. org/10.7589/0090-3558-20.4.303.

Poulin R. Determinants of host-specificity in parasites of freshwater fishes. Int J Parasitol 1992; 22(6): 753-758. PMid:1428509. http:// dx.doi.org/10.1016/0020-7519(92)90124-4.

Reis RE, Kullander SO, Ferraris CJ Jr. Check list of the freshwater fishes of South and Central America. Porto Alegre: Edipucrs; 2003.

Reite OB. The rodlet cells of teleostean fish: their potential role in host defence in relation to the role of mast cells/eosinophilic granule cells. Fish Shellfish Immunol 2005; 19(3): 253-267. PMid:15820126. http:// dx.doi.org/10.1016/j.fsi.2005.01.002.

Rios FS, Oba ET, Fernandes MN, Kalinin AL, Rantin RT. Erythrocyte senescence and haematological changes induced by starvation in the neotropical fish traíra, Hoplias malabaricus (Characiformes, Erythrinidae). Comp Biochem Physiol A Mol Integr Physiol 2005; 140(3): 281-287. PMid:15792593. http://dx.doi.org/10.1016/j.cbpb.2004.12.006.

Roberts RJ. Fish pathology. 4th ed. Iowa: Wiley-Blackwell; 2012.

Rotta MA. Aspectos Biológicos e Reprodutivos para a Criação da Tuvira (Gymnotus sp.) em Cativeiro - I. Corumbá: Embrapa Pantanal; 2004.

Santos CP, Borges JN, Fernandes ES, Pizani APCL. Nematoda. In: Pavanelli GC, Takemoto RM, Eiras JC. Parasitologia de peixes de água doce do Brasil. Maringá: Eduem; 2013. p. 333-352. 
Smith JW. The abundance of Anisakis simplex L3 in the body-cavity and flesh of marine teleosts. Int J Parasitol 1984; 14(5): 491-495. http:// dx.doi.org/10.1016/0020-7519(84)90030-4.

Székely CS, Pazooki J, Molnár K. Host reaction in paratenic fish hosts against 3rd stage larvae of Anguillicola crassus. Dis Aquat Organ 1996; 26(3): 173-180. http://dx.doi.org/10.3354/dao026173.

Takashima F, Hibiya T. An atlas of fish histology: normal and pathological features. Tokyo: Kodansha Ltda; 1995.

Valtonen ET, Haaparanta A, Hoffmann RW. Occurrence and histological response of Raphidascaris acus (Nematoda: Ascaridoidea) in roach from four lakes differing in water quality. Int J Parasitol 1994; 24(2): 197-206. PMid:8026896. http://dx.doi.org/10.1016/0020-7519(94)90026-4.
Ventura AS, Ishikawa MM, Gabriel AMA, Silbiger HLN, Cavichiolo F, Takemoto RM. Histopathology from liver of tuvira (Gymnotus spp.) parasitized by larvae of nematodes. Cienc Rural 2016; 46(7): 1233-1239. http://dx.doi.org/10.1590/0103-8478cr20150881.

Vieira KRI, Vicentin W, Paiva F, Pozo CF, Borges FA, Adriano EA, et al. Brevimulticaecum sp. (Nematoda: Heterocheilidae) larvae parasitic in freshwater fish in the Pantanal wetland, Brazil. Vet Parasitol 2010; 172(3-4): 350-354. PMid:20684864. http://dx.doi.org/10.1016/j. vetpar.2010.05.003.

Wolke RE. Piscine macrophage aggregates: a review. Annu Rev Fish Dis 1992; 2: 91-108. http://dx.doi.org/10.1016/0959-8030(92)90058-6.

Xi WG, Jin LZ. A novel method for the recovery of Toxocara canis in mice. J Helminthol 1998; 72(2): 183-184. PMid:9687601. http://dx.doi. org/10.1017/S0022149X00016382. 